\title{
17. PETROLOGY AND PROVENANCE OF SANDS AND GRAVELS FROM THE MIDDLE AMERICA TRENCH AND TRENCH SLOPE, SOUTHWESTERN MEXICO AND GUATEMALA ${ }^{1}$
}

\author{
Robert H. Enkeboll, ${ }^{2}$ H. Esmaili \& Associates, Berkeley, California
}

\begin{abstract}
The composition of sand from the Middle America Trench and slope varies significantly along strike and reflects local source areas with contrasting rock types. Terrigenous sands offshore Guerrero and Oaxaca, Mexico, are rich in quartz, feldspar, and metamorphic rock fragments and closely reflect the schist and gneiss that dominate the source area. The average composition of the fine sands is $\mathrm{Q}_{31} \mathrm{~F}_{50} \mathrm{~L}_{19}$ and that of the coarse sands is $\mathrm{Q}_{41} \mathrm{~F}_{22} \mathrm{~L}_{37}$. Plagioclase and potassium feldspar occur in roughly equal amounts; biotite and hornblende are the most common mafic minerals.

Offshore Guatemala, terrigenous sands are volcaniclastic and rich in pyroclastic material, reflecting a source area dominated by Tertiary and Quaternary volcanic rocks and unconsolidated pyroclastic deposits. The average composition of the volcaniclastic sands is $\mathrm{Q}_{1} \mathrm{~F}_{43} \mathrm{~L}_{56}$. Almost all feldspar is plagioclase, almost all rock fragments are volcanic, and the ratio of glass shards to total rock fragments is 0.67 . Pyroxene is the dominant mafic material.

Gravel fragments from the base of scarps on the lower slope offshore Guatemala include prehnite-pumpellyite facies metabasite and laumontite-bearing argillite. The timing of the metamorphism is uncertain, but the common occurrence of prehnite-pumpellyite facies rocks in subduction complexes and their rarity on the seafloor suggest that the metamorphism of at least the metabasite is related to subduction and accretion along the Middle America Trench. These apparently "recycled" gravels form small olistostromes on the lower slope of this modern subduction system.
\end{abstract}

\section{INTRODUCTION}

In this paper I describe the mineralogy, petrology, and provenance of late Pleistocene to Holocene (McMillen et al., 1980) sands and gravels from the continental margin of two portions of the Middle America Trench. Sediment was collected with a Ewing-type piston corer with a maximum length of $40 \mathrm{ft}$. $(13.3 \mathrm{~m})$ by the University of Texas Marine Science Institute for IPOD drilling offshore southwestern Mexico on Leg 66 and offshore Guatemala on Leg 67. I relate the composition of terrigenous sand recovered offshore to contrasting geologic and tectonic settings in the two areas. The data provides a modern example of the marked changes in sand composition that can occur along a continuous subduction system.

\section{METHODS}

From 24 cores recovered offshore Guatemala, I sampled 31 visually observed sand layers and from 13 cores recovered offshore southwestern Mexico I collected 21 sand and gravel samples. In addition, I collected eight samples of gravel from three cores from lower slope scarps offshore Guatemala. Because most sand layers are less than $5 \mathrm{~cm}$ thick, sample sizes usually did not exceed $10 \mathrm{cc}$. Samples from the Guatemala forearc include 4 samples from the shelf, 3 samples from a submarine canyon, 25 samples from the lower slope, 2 samples from the trench and 5 samples from seaward of the trench. Samples from the southwestern Mexico forearc region include 3 samples from the lower slope, 16 samples from the trench, and 2 samples from seaward of the trench.

Samples were soaked 8 to 10 hours in a $15 \%$ solution of hydrogen peroxide and wet-sieved to obtain the fraction greater than 0.0625 $\mathrm{mm}$. Particle size distributions for 1- to 2-cc splits of this fraction were determined using a settling-tube method at the University of Texas Marine Science Institute. Very fine- and fine-grained sand predomi-

\footnotetext{
1 Initial Reports of the Deep Sea Drilling Project, Volume 66.

2 Present address: 380 Bretano Way, Greenbrae, California, 94904.
}

nates in piston cores from offshore both southwestern Mexico and Guatemala with the exception of coarse sand in one core from the trench offshore Mexico (Table 1).

The coarse fraction was mounted in epoxy on a petrographic slide and was cut and ground to standard thin section thickness for petro-

Table 1. Particle size distribution parameters of selected sand samples.

\begin{tabular}{llccc}
\hline $\begin{array}{c}\text { Core No./ } \\
\text { Depth }(\mathrm{cm})\end{array}$ & Environment & $\begin{array}{c}\text { Mean } \\
(\mathrm{mm})\end{array}$ & $\begin{array}{c}\text { Median } \\
(\mathrm{mm})\end{array}$ & $\begin{array}{c}\text { Standard } \\
\text { Deviation }\end{array}$ \\
\hline $25-441$ & Seaward of trench & 0.137 & 0.133 & 0.487 \\
$25-548$ & Seaward of trench & 0.125 & 0.128 & 0.565 \\
$26-25$ & Trench & 0.162 & 0.165 & 0.405 \\
$26-80$ & Trench & 0.187 & 0.189 & 0.412 \\
$27-10$ & Trench & 0.875 & 0.871 & 0.659 \\
$27-65$ & Trench & 0.770 & 0.812 & 0.269 \\
$27-105$ & Trench & 0.842 & 0.812 & 0.873 \\
$27-145$ & Trench & 0.865 & 0.908 & 0.610 \\
$27-185$ & Trench & 0.987 & 1.000 & 0.812 \\
$27-225$ & Trench & 0.844 & 0.983 & 0.656 \\
$28-428$ & Lower slope & 0.118 & 0.118 & 0.453 \\
$28-487$ & Lower slope & 0.117 & 0.117 & 0.447 \\
$28-496$ & Lower slope & 0.124 & 0.124 & 0.405 \\
$31-161$ & Trench & 0.111 & 0.102 & 0.621 \\
$31-200$ & Trench & 0.160 & 0.154 & 0.818 \\
$31-242$ & Trench & 0.128 & 0.120 & 0.580 \\
$31-342$ & Trench & 0.134 & 0.131 & 0.552 \\
$31-385$ & Trench & 0.330 & 0.339 & 0.418 \\
$13-205$ & Lower slope & 0.137 & 0.134 & 0.401 \\
$13-216$ & Lower slope & 0.181 & 0.177 & 0.577 \\
$13-442$ & Lower slope & 0.103 & 0.100 & 0.358 \\
$14-668$ & Trench & 0.070 & 0.068 & 0.543 \\
$15-559$ & Seaward of trench & 0.211 & 0.218 & 0.375 \\
$16-297$ & Seaward of trench & 0.123 & 0.117 & 0.410 \\
$16-368$ & Seaward of trench & 0.125 & 0.120 & 0.410 \\
$16-586$ & Seaward of trench & 0.216 & 0.212 & 0.684 \\
$17-615$ & Trench & 0.075 & 0.068 & 0.425 \\
\hline
\end{tabular}

Note: Sand distributions were analyzed by means of a sedimentation tube with an automatically recording strain gauge at the bottom of the tube. 
graphic analysis and point-counting. Slides were stained with a concentrated solution of sodium cobaltinitrite to aid in the identification of potassium feldspar and with a concentrated solution of amaranth to aid in the identification of plagioclase. I identified and line-counted 300 to 800 noncalcareous grains per slide using, with one exception, the methods and categories discussed by Dickinson (1970). I include fragments made up of an aggregate of minerals as lithic fragments, whereas Dickinson counts separately the individual minerals making up such fragments. This procedure enables the point-count data to be responsive to rock fragment textures and also aids in the interpretation of source rock types. This difference in methodology is of significance only for the coarse-grained sands from Core 27, where fragments consisting of aggregates of minerals are abundant. All other sands are so fine grained that aggregate mineral fragments are rare. The significance of the methodology used here will be discussed further in the section on the mineralogy of sands from offshore southwestern Mexico.

\section{TECTONIC AND GEOLOGIC SETTING}

The tectonic setting of the Middle America Trench has been described in detail in several recent articles (Ladd et al., 1978; Karig et al., 1978; Shipley et al., 1980; Moore et al., 1979) and will only be briefly summarized here. The salient feature is that although the Cocos Plate is being consumed along the entire length of the Middle America Trench (Molnar and Sykes, 1969), the morphology of the trench and the onland geology change abruptly at the Tehuantepec Ridge (Fig. 1). Northwest of this ridge the trench offshore southwestern Mexico (Fig. 2) is about $5200 \mathrm{~km}$ deep and consists of a series of discrete elongate basins that appear to contain sediment. The shelf is narrow and metamorphic, and plutonic rocks extend to the coast. Geophysical profiling (Ladd et al., 1978) suggest that these rocks underlie the shelf and upper part of the inner trench wall. The shelf and lower slope in the study area is cut by a submarine canyon that empties into the trench near where Core 27 (Fig. 2) was recovered and heads near the mouth of Rio Ometepec, the major drainage basin in this part of southwestern Mexico. The geology onland of the southwestern Mexico study area is dominated by $68 \%$ Precambrian schist and gneiss. Other rock types include plutonic, volcanic, and sedimentary rocks that occur in approximately equal amounts.

The present morphology and geology of the southwestern Mexico portion of the Middle America Trench reflect in part a pre-late Miocene tectonic erosion or truncation of the continental margin (Karig et al., 1978). The imprint of this event is still very prominent and greatly influences the composition of sediment being deposited in the trench north of the Tehuantepec Ridge.

Offshore Guatemala (Fig. 3) the trench deepens to approximately 6000 meters, and the trench bottom is narrow and apparently lacks any significant sediment fill. The shelf is about $110 \mathrm{~km}$ wide and is associated onland with a 50-km-wide coastal plain. An extensive magmatic arc, with numerous stratovolcanoes exceeding $10,000 \mathrm{ft}$., rises abruptly from the coastal plain. The prominent Quaternary volcanoes were built upon the southern edge of an uplifted Miocene-Pliocene volcanic terrain. This terrain is underlain by andesitic and dacitic lava flows and associated deposits of airfall tuffs, lahars, and fluvial and lacustrine tuffaceous sediment (Williams, 1960). The Quaternary volcanoes are all composite cones made up chiefly of pyroxene andesite lavas and fragmental ejecta. The volcanoes have pro-

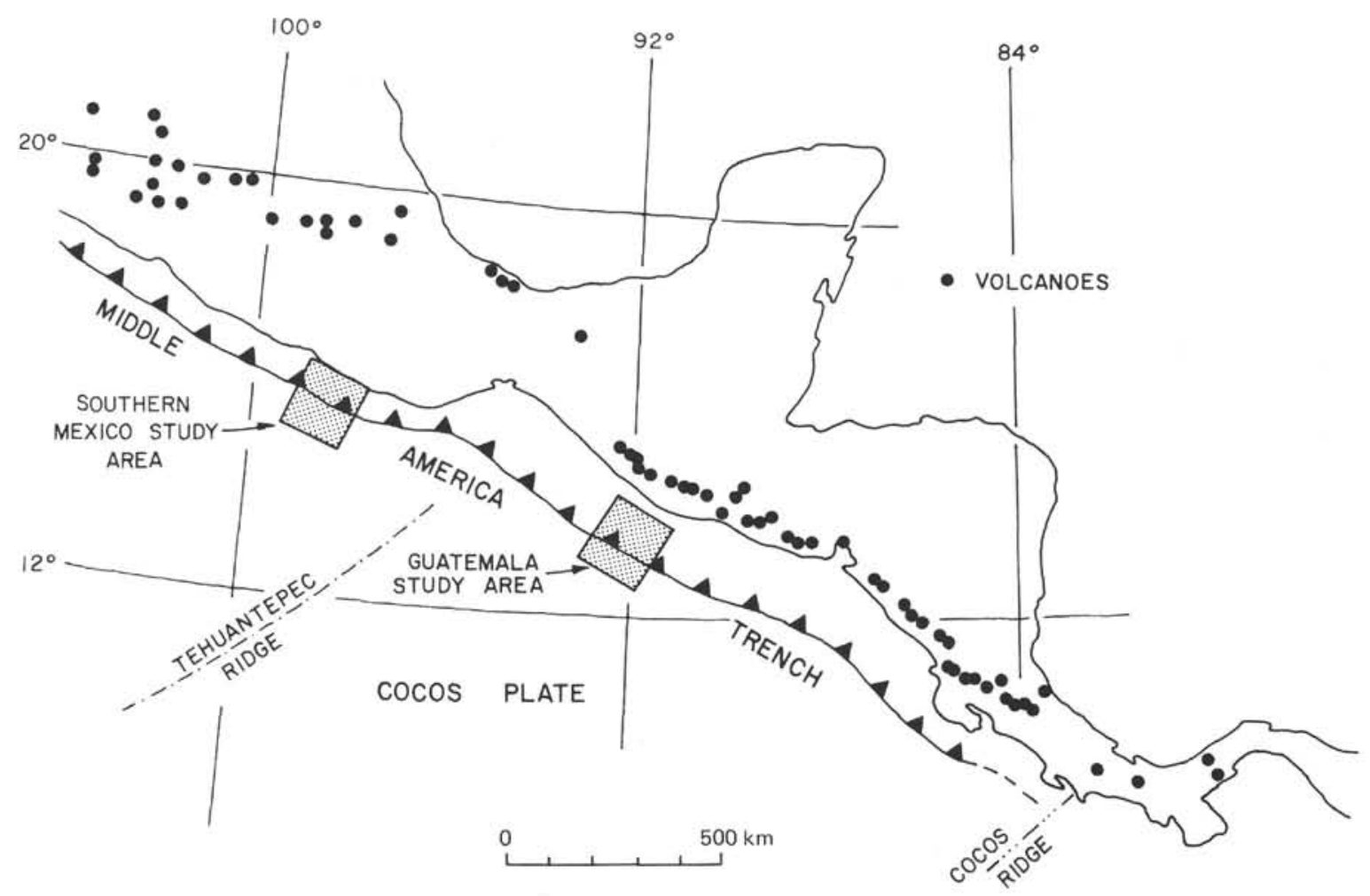

Figure 1. Tectonic setting showing the Guatemala and southern Mexico study areas and prominent volcanoes. 


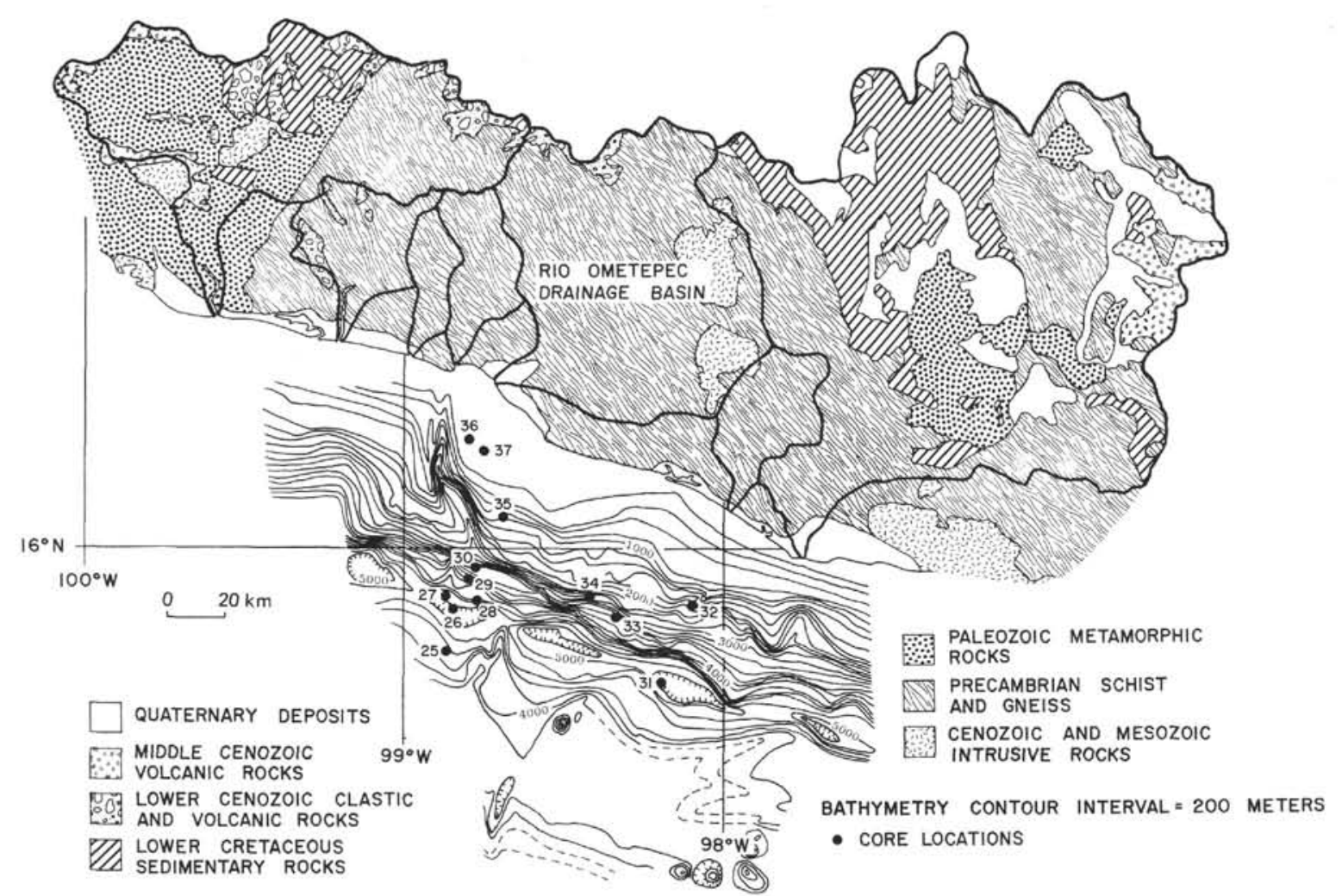

Figure 2. Southern Mexico study area showing core locations and onland geology with drainage basins superimposed (geology from Salas [1968]; bathymetry from Shipley et al. [1980]).

duced large amounts of volcaniclastic material, and the highland plateau is covered by thick accumulations of airfall pumice. Valleys contain thick accumulations of glowing avalanche and lahar deposits.

No large drainage system dominates the Pacific slope of Guatemala adjacent to the study area, and terrestrial sediment reaching the ocean is not obviously derived from a single drainage system. Drainage basins onland from where the cores were collected consist of $57 \%$ coastal plain deposits consisting mostly of tuffaceous and pumiceous fluvial sediments, $26 \%$ Tertiary volcaniclastic deposits, $12 \%$ Quaternary andesitic volcanoes, and 3\% Quaternary pumice. Surface exposures of nonvolcanic rocks are almost entirely lacking; they include several small outcroppings of plutonic rocks and limestone.

\section{MINERALOGY AND PETROLOGY}

In this section I briefly describe the macroscopic characteristics of sediment cored offshore southwestern Mexico and Guatemala and describe in detail the mineralogy, petrology, and composition of terrigenous sands from both areas.

\section{Southwestern Mexico Continental Margin}

Cores from the shelf (Fig. 4) consist almost entirely of shelly, foraminiferal, algal sand. Because of the paucity of inorganic constituents, I did not point-count samples from these cores. Cores from the lower slope were recovered from small scarps, slope basins, and a submarine canyon. Despite the diverse environments, cores are dominated by micaceous sandy mud; few sandy layers occur on the lower slope. Sand layers are more abundant in the trench, and Core 27 , recovered from the base of a submarine canyon, consists entirely of apparently nonbedded, coarse-grained, clean, and well-rounded sand. Seaward of the trench, sand is rare and occurs in only a few thin layers.

Two distinct groupings of samples occur on the Q-F-L diagram of sands from offshore southwestern Mexico (Fig. 5). This is a function of grain size and does not necessarily imply different source areas. In the coarsegrained sands of Core 27, I included polycrystalline fragments rich in quartz and feldspar in the lithic end member of the Q-F-L diagram. As a result, the plot for samples from this core is more representative of a QmFLt plot of Dickinson and Suczek (1979). Petrographic examination of the quartzo-feldspathic polycrystalline fragments revealed that they contain slightly more feldspar than quartz. Thus if the coarse-grained sands were broken down they apparently would plot similarly to the fine-grained sands. Because of the strong effect grain size has on the point-count data (Table 2) and the Q-F-L plot, I will discuss the finegrained sands separately from the coarse-grained sands.

The average composition of the fine-grained sands is $\mathrm{Q}_{31} \mathrm{~F}_{50} \mathrm{~L}_{19}$. Monocrystalline quartz dominates the quartz end-member. The ratio of chert to total quartzose grains averages 0.06 , and the ratio of polycrystalline quartz to total quartzose grains in 0.10 .

Plagioclase feldspar typically is slightly more abundant than potassium feldspar. The ratio of plagioclase 


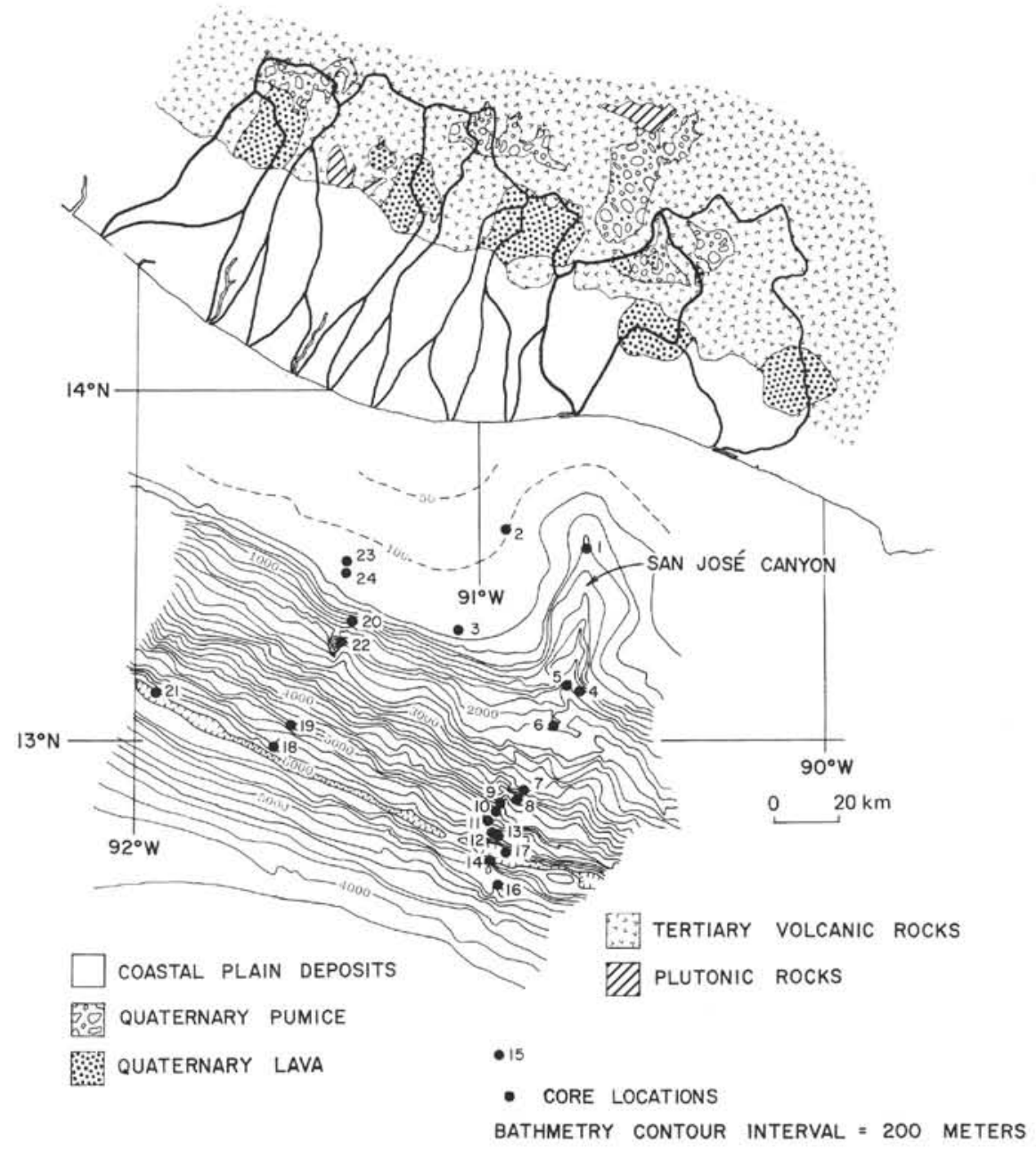

Figure 3. Guatemala study area showing core locations and onland geology with drainage basins superimposed (geology from Williams [1960]; bathymetry from Ladd et al. [1978]).

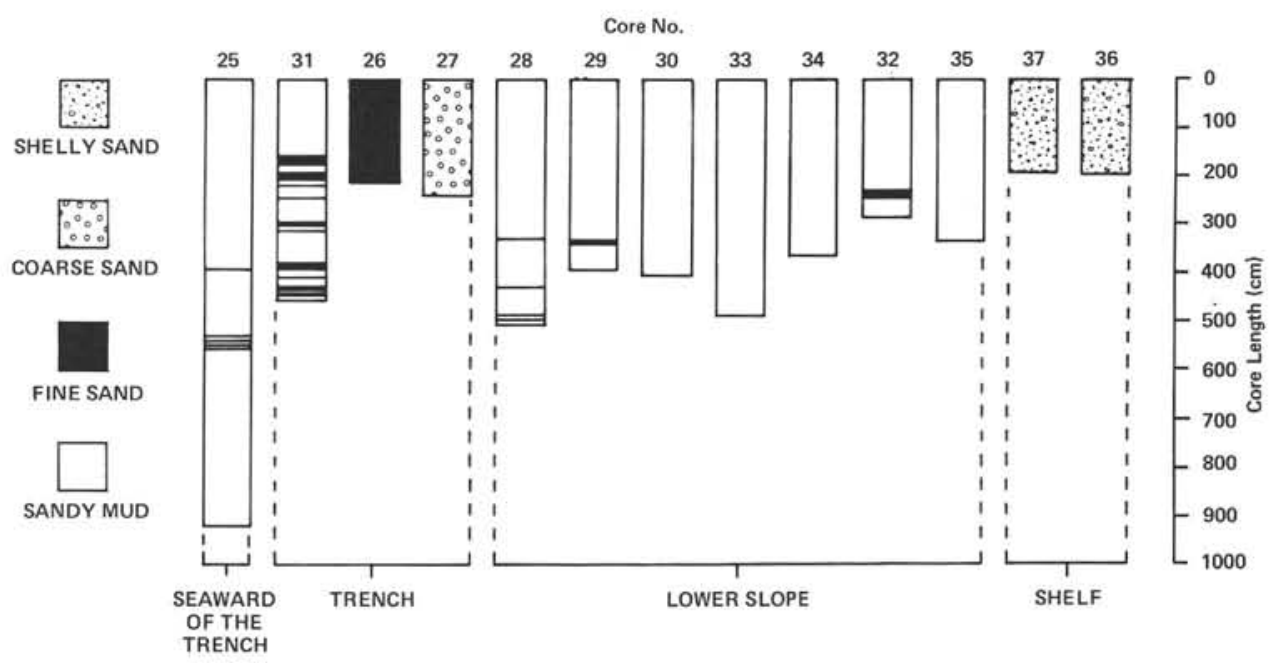

Figure 4. Log of cores recovered offshore Oaxaca, Mexico (cores described by Trent Haines, University of Texas Marine Science Institute). 


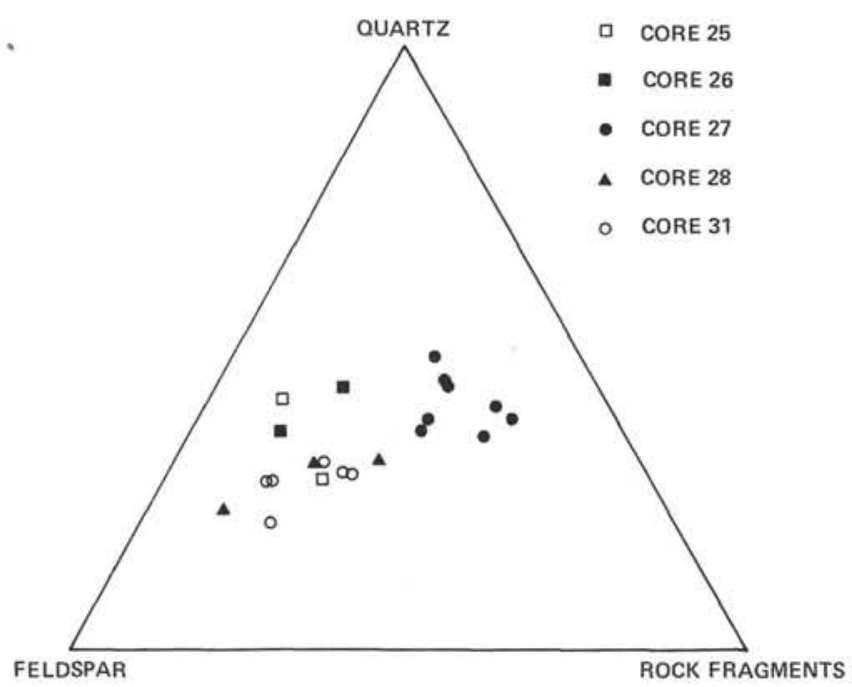

Figure 5. Ternary plot showing frequencies of major grain categories in sand samples from cores collected offshore Oaxaca, Mexico.

feldspar to total feldspar averages 0.58 and ranges from 0.72 to 0.33 . The $\mathrm{P} / \mathrm{F}$ ratio, however, usually is fairly constant among the fine sands from the different cores.

Lithic fragments consist, in order of decreasing abundance, of metamorphic rock fragments $(\bar{X}=8 \%)$, plutonic rock fragments $(\bar{X}=6 \%)$, sedimentary rock fragments $(\bar{X}=2 \%)$, and volcanic rock fragments $(\bar{X}=$ $2 \%$ ). Metamorphic rock fragments include those fragments in which metamorphic minerals are identifiable, the most common of which are epidote and muscovite.

Mafic and accessory minerals average almost $20 \%$ of the grains point-counted in the fine-grained sands. Biotite, averaging $57 \%$, and hornblende, averaging $19 \%$, are the most abundant mafic minerals. Both green and brown varieties of hornblende occur. Other minerals represented include epidote, muscovite, chlorite, garnet, zircon, hematite, pyroxene, and undifferentiated opaque minerals.

Very coarse-grained sands are present in Core 27, recovered from a depth of 4800 meters from the landward edge of the trench basin in the vicinity of the prominent submarine canyon. The core consists entirely of apparently nonbedded, clean, moderately well-rounded sand. The average composition of the sand from this core is $\mathrm{Q}_{41} \mathrm{~F}_{22} \mathrm{~L}_{37}$. Quartz is largely monocrystalline, although polycrystalline quartz to total quartzose grains averages 0.18 and the ratio of chert to total quartzose grains averages 0.04 . Monocrystalline quartz fragments commonly show undulatory extinction. Many of the polycrystalline quartz fragments contain elongate grains with choppy irregular borders. If the elongation is extreme enough, I included the fragments as tectonic fragments and lumped them in the lithic end member of the Q-F-L diagram. Dimensional preferred orientation of the elongate quartz crystals is characteristic of strained and regionally metamorphosed quartzose rocks (Spry, 1969).

In most of the sand from Core 27, potassium feldspar is slightly more abundant than plagioclase feldspar; the ratio of plagioclase feldspar to total feldspar averages 0.46 . Although I did not systematically determine plagioclase compositions, albite twinning indicates the calcium content of plagioclase is low (albite to oligoclase).

Because these sands are so coarse grained, lithic fragments are much more abundant (average $41 \%$ ) than in the cores where the sand is fine-grained (average 19\%). Plutonic rock fragments average $17 \%$ and are about equally as abundant as metamorphic rock fragments, which average $14 \%$. Sedimentary $(\bar{X}=3 \%$ ) and volcanic $(\bar{X}=2 \%)$ rock fragments occur in only minor amounts. The ratio of volcanic rock fragments to total rock fragments averages 0.04 .

Mafic minerals average only $3 \%$ of the total pointcounted grains in the coarse-grained sands. As a result, estimates of the relative abundances of mafic minerals are not warranted. Most sand samples contain biotite and hornblende, with biotite more abundant. Epidote, sphene, opaque minerals, and pyroxene also occur but are much less abundant.

The mafic and accessory minerals occurring in both the fine-grained and coarse-grained sands generally compare fairly well to the heavy minerals reported by Ross (1971) from the northern portion of the Middle America Trench. He reports a significant orthopyroxene component that does not appear offshore southwestern Mexico. This is probably due to the diffuse magmatic arc along the Mexico section of the trench being much closer to the coast at the northern end than at the southern end (see Fig. 1). Biotite occurs much more abundantly offshore southwestern Mexico than from the northern portion of the trench. The reason for this is unclear, though it may be due to differences in the composition of the source rocks or to differences in analytical techniques; because of the small sample size, I did not separate heavy minerals from the light minerals. It is possible that biotite may occur as a light mineral where its relative importance is obscured by the abundance of quartz and feldspar. Another possibility is that contrasting hydraulic properties of micas and tabular minerals may be influencing the distribution of biotite.

\section{Guatemala Continental Margin}

Cores from the shelf (Fig. 6) consist predominantly of fine-grained, shelly foraminiferal sand. Four samples, however, had a large enough terrigenous component to warrant point-counting. Other cores are dominated by sandy mud. Sand layers typically do not make up more than $5 \%$ of the sediment in a core and are usually less than $5 \mathrm{~cm}$ thick. Sediment from San Jose Canyon is dominated by a very fine-grained silty mud but also contains thin layers of very fine-grained foraminiferal sand. Lower slope basin sediment consists of about $98 \%$ very fine-grained sandy mud and $2 \%$ medium- to very fine-grained muddy sand and sandy ash. Cores from the lower slope that are not associated with basins or scarps typically consist entirely of very fine-grained sandy mud. Thin sand layers account for about $3 \%$ of the sediment in the trench. Angular gravel occurs in all 
Table 2. Tabulated point-count data for sands recovered offshore Oaxaca, Mexico.

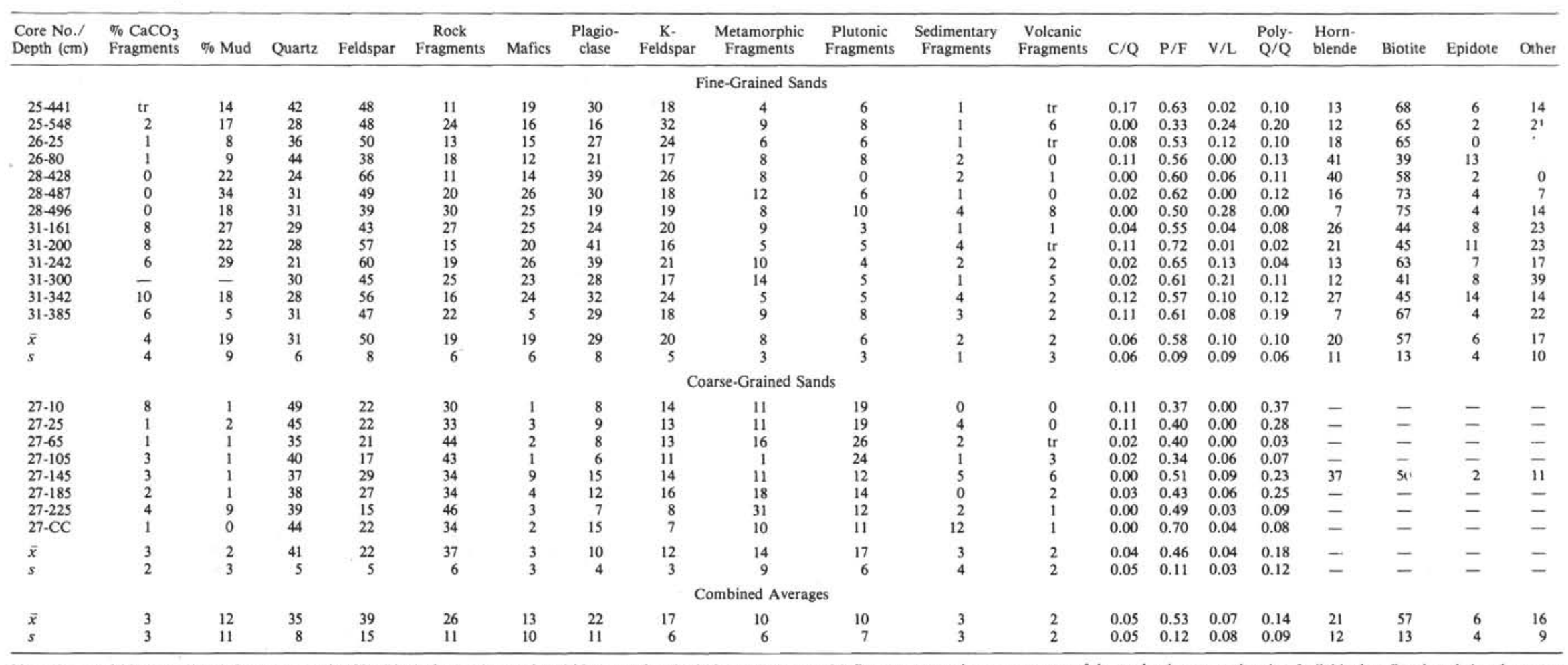

Note: Quartz, feldspar, and rock fragments total $100 \%$. Plagioclase and potassium feldspar total to the feldspar percentage. Mafics are presented as a percentage of the total point-counted grains. Individual mafic mineral abundances are percentages of the total mafic minerals point counted. $\mathrm{C} / \mathrm{Q}$ is the ratio of chert to total quartzose grains. $\mathrm{P} / \mathrm{F}$ is the ratio of plagioclase to total feldspar. $\mathrm{V} / \mathrm{L}$ is the ratio of volcanic rock fragments to total rock fragments. Poly- $\mathrm{Q} / \mathrm{Q}$
is the ratio of polycrystalline quartz grains to total quartzose grains. $\mathrm{Tr}=$ trace in Tables $2-4$. 


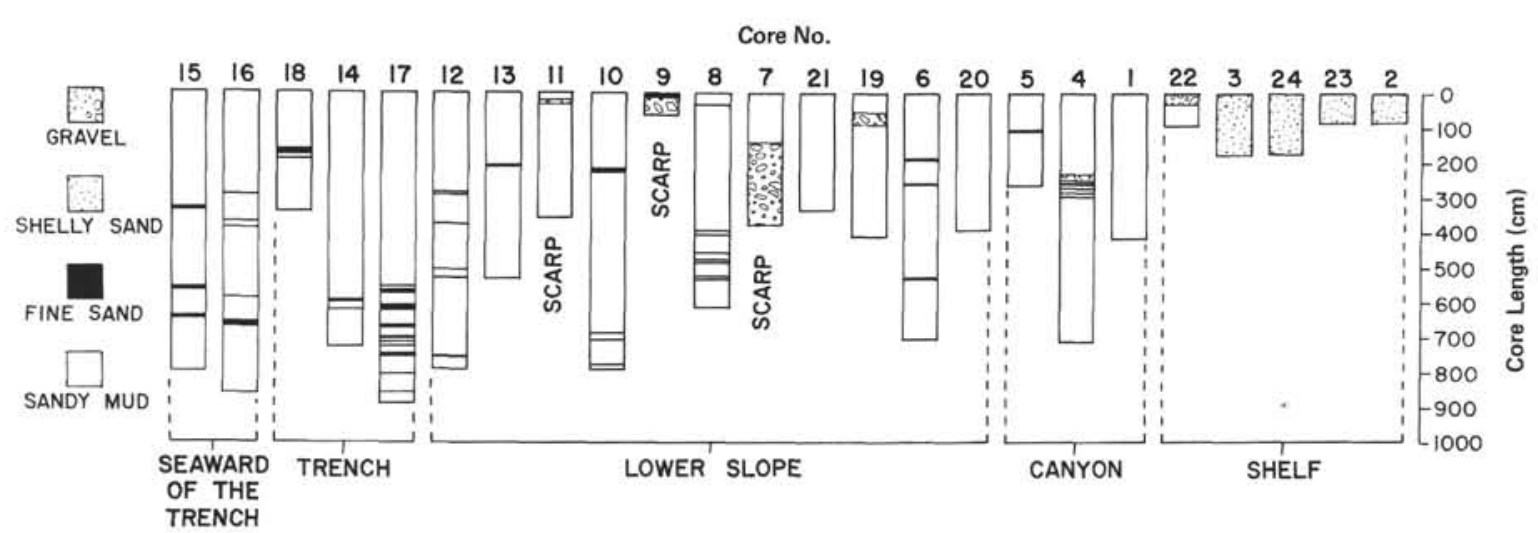

Figure 6. Log of cores recovered offshore Guatemala (cores described by Trent Haines, University of Texas Marine Science Institute).

cores (three) recovered from near the base of scarps on the lower slope. Both clean and muddy gravel occurs, and the amount in a core is quite variable.

All the sand recovered from offshore Guatemala beyond the shelf is rich in volcaniclastic material. These volcaniclastic sands are made up of varying amounts of pyroclastic material, which is dominated by plagioclase and mafic mineral euhedra, glass shards, and nonvitric volcanic rock fragments. Quartz and potassium feldspar rarely are present, and some sand layers contain rip-up clasts.

The average composition of the volcaniclastic sands is $\mathrm{Q}_{1} \mathrm{~F}_{43} \mathrm{~L}_{56}$ (Fig. 7, Table 3). Quartz most commonly is monocrystalline and unstrained, and feldspar is almost entirely plagioclase; the ratio of plagioclase to total feldspar averages 0.99 .

Lithic fragments average $41 \%$ of the point-counted grains and are dominated by glass shards which range from 82 to $8 \%$. Both bubble-pumice and bubble-wall shards occur in approximately equal amounts. Shards are almost always very angular, clear, and colorless. Nonvitric volcanic rock fragments average $16 \%$ of the point-counted grains. Their textures indicate that they

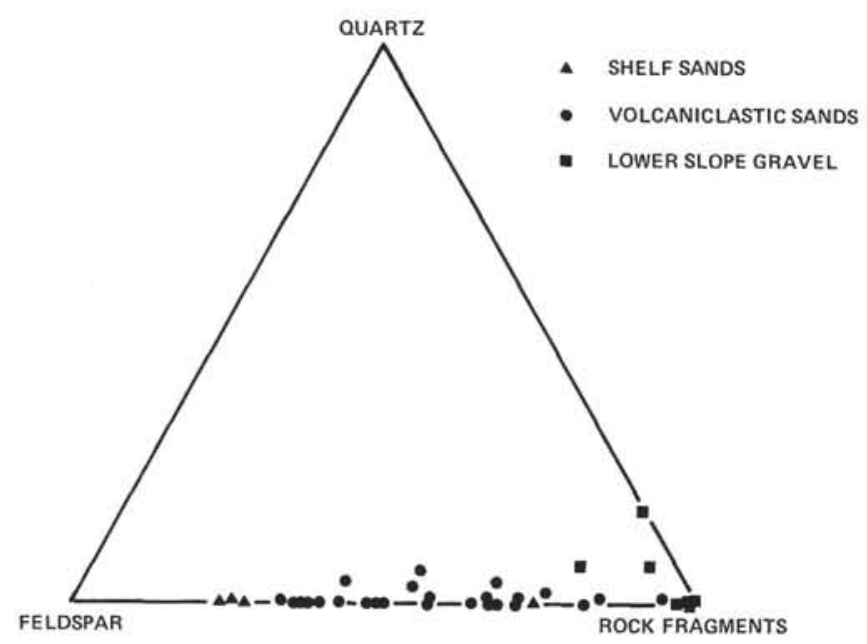

Figure 7. Ternary plot showing frequencies of major grain categories in samples from offshore Guatemala. were derived from a predominantly andesitic source with some dacite also present. Following the classification system of Dickinson (1970), microlitic volcanic rock fragments appear to be most common. Lathy varieties also occur but in lesser amounts. Other rock fragments include minor amounts of calcite-cemented quartzose sandstone and metamorphic rock fragments of indeterminate origin.

Mafic minerals average $11 \%$ of the total grains pointcounted. Pyroxene is most abundant and averages $38 \%$ of the mafic minerals. The ratio of clinopyroxene to total pyroxene averages 0.58 . Hornblende and biotite both average $25 \%$ of the mafic minerals; the percentage of biotite, however, is more variable than that of hornblende. Opaque minerals and epidote occur in minor amounts.

Rip-up clasts occur in about half the cores recovered from the lower slope and trench offshore Guatemala. Their occurrence appears to be random with respect to the specific depositional environment (i.e., slope scarp, slope basin, trench, etc.). Rip-up clasts are light brown and often contain radiolarians and small fragments of glass. Although they may be mistaken for mud matrix, their anomalously large size and lighter color are usually distinctive.

The abundance of unaltered, extremely angular, delicate-shaped glass shards and broken, unaltered, mafic mineral euhedra in the volcaniclastic sands indicates a very recent pyroclastic origin and very little reworking or transportation. These sands were derived either from the erosion of very recent pyroclastic deposits or were deposited directly from explosive eruptions of the large Quaternary volcanoes. These recent volcanoes and associated Quaternary pyroclastic debris cover only $15 \%$ of the Pacific slope of Guatemala adjacent to the study area. Apparently the contribution of sediment from recent volcanism is far greater than that contributed by the erosion of older volcanic rocks.

Poorly sorted, angular gravel is present in Cores 7, 9, and 11 , which were recovered from short scarps separating small basins on the lower slope. The average composition of the gravels is $\mathrm{Q}_{4} \mathrm{~F}_{3} \mathrm{~L}_{93}$ (Fig. 7, Table 4). Gravel in Core 7 consists of angular fragments of metabasalt and metadiabase with lesser amounts of red radiolarian 
Table 3. Tabulated point-count data for sands recovered offshore Guatemala.

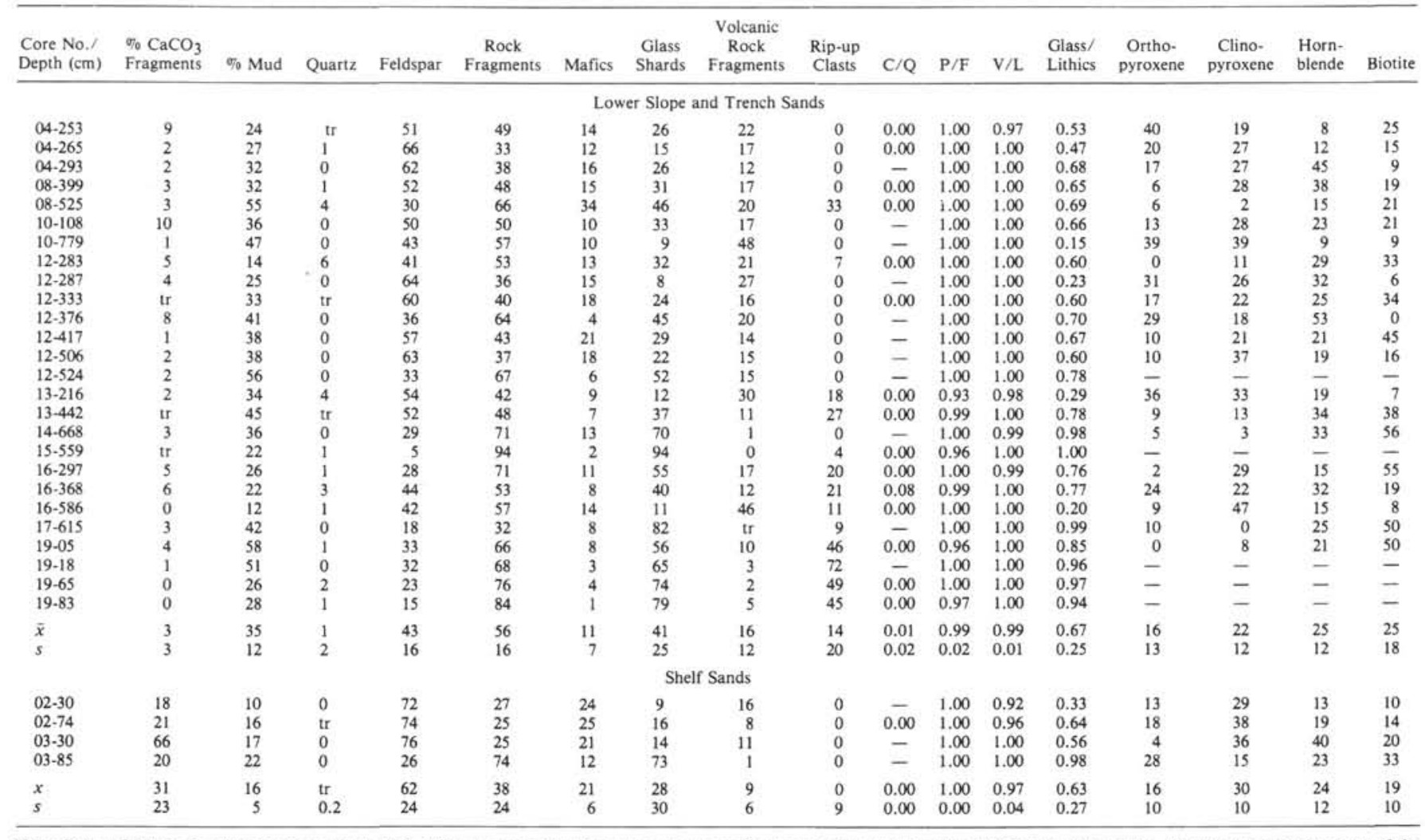

Note: Quartz, feldspar, and rock fragments total $100 \%$. The percentage of mafics is the percentage of the total point-counted grains. Individual mafic mineral abundances are percentages of the total mafic minerals point counted. $\mathrm{C} / \mathrm{Q}$ is the ratio of chert to total quartzose grains. $\mathrm{P} / \mathrm{F}$ is the ratio of plagioclase to total feldspar. $\mathrm{V} / \mathrm{L}$ is the ratio of volcanic rock fragments to the total rock fragments. Rip-up clast abundances are the percentage of total point-counted grains but are not included as rock fragments.

chert, white chert, and serpentine. Gravel in Cores 9 and 11 is dominated by mildly consolidated, extremely angular fragments of claystone or argillite.

Although the metabasalt and metadiabase fragments are badly altered, relict textures and minerals are recognizable. Fragments consist of variable amounts of plagioclase laths, pyroxene microphenocrysts, and groundmass. Although plagioclase is extensively altered to very fine-grained, optically irresolvable material, lath edges can usually be observed. The most common pyroxene is a clinopyroxene. Internally it is not extensively altered, although grain boundaries are usually poorly preserved. Intergranular and intersertal textures can be recognized in the metabasalt fragments and subophitic texture in the metadiabase fragments.

The groundmass of the gravel fragments is extensively altered to (in order of decreasing abundance) palagonite, pumpellyite, serpentine, prehnite, chlorite, and epidote. Veins of pumpellyite are common.

Sandy argillite gravel fragments typically are angular and very thin. They consist mostly of a dark brown, murky, optically irresolvable material. A few fragments were observed to be cut by veins filled with laumontite.

Prehnite and pumpellyite in the metabasite gravel fragments indicate that these rocks have experienced a low-grade, presumably prehnite-pumpellyite facies metamorphism. The place and timing of this metamorphism are uncertain. No similar rocks, however, have ever been reported onland on the Pacific slope of
Guatemala; thus metamorphism must have occurred either at the ocean floor, subduction zone, or accretionary zone. Although more thorough sampling is needed to understand more fully the significance of these gravels, it appears that prehnite-pumpellyite facies basalt and diabase are exposed in scarps on the inner trench wall and that small olistostromes are accumulating on the lower slope offshore Guatemala.

\section{PROVENANCE}

The drainage basins onland adjacent to the southwestern Mexico core locations are dominated by schist and gneiss with lesser amounts of plutonic rocks, sedimentary rocks and volcanic rocks. The composition of both fine- and coarse-grained sands offshore is consistent with derivation from such a source terrane. In these sands an abundance of polycrystalline quartz grains with such metamorphic textures as dimensional preferred orientation, as well as numerous quartzofeldspathic grains containing metamorphic minerals, indicates that the source terrane is rich in silicic, coarsegrained metamorphic rocks.

Deposition of terrigenous sand offshore southwestern Mexico appears to be restricted primarily to areas near the trench. Few sand layers are present in any of the cores from the lower slope. It is surprising that more terrigenous sand was not encountered on the lower slope or in the trench, considering the combination of high relief immediately onshore and a narrow shelf offshore. 


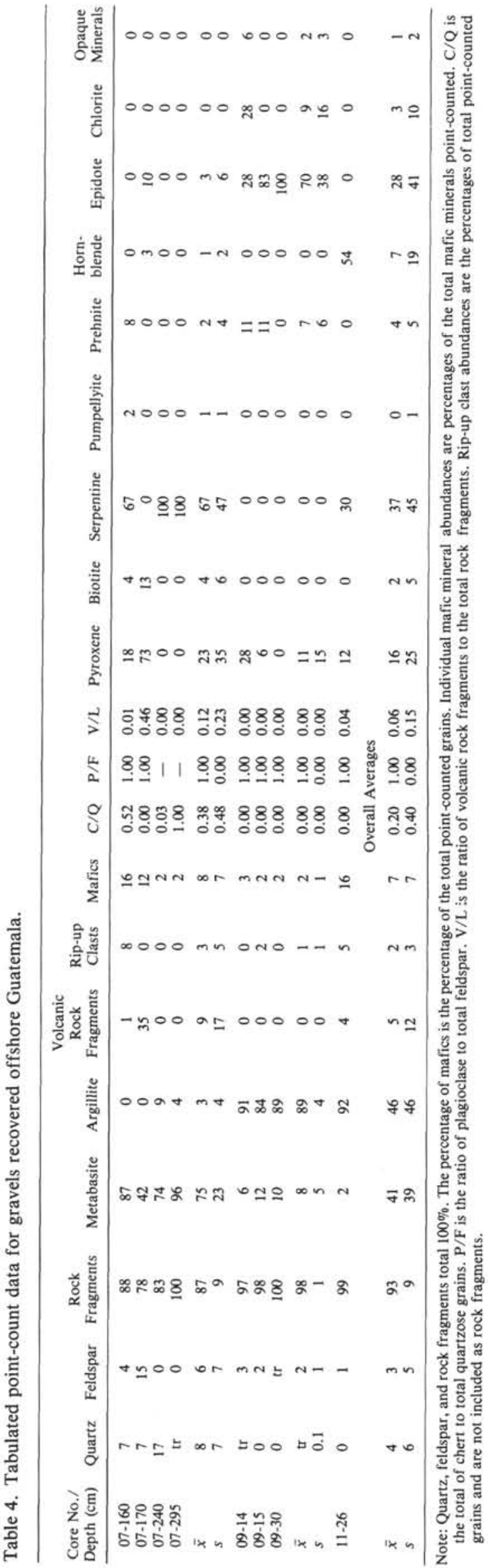

The thick, unbedded sequence of coarse sand in Core 27 probably was transported into the trench through the submarine canyon that incises into the shelf near where Rio Ometepec enters the ocean. This is the dominant drainage basin onland of the core locations and possibly is a major source for terrigenous sediment deposited offshore.

On the Q-F-L diagram, the composition of fine sands offshore southwestern Mexico plot in the field outlined by Dickinson and Suczek (1979) corresponding to very immature sediment derived from a continental block provenance. This agrees well with the onland geology, high relief, and narrow shelf characteristic of this portion of southwestern Mexico.

The composition of terrigenous sands offshore Guatemala closely reflects their derivation from the almost exclusively volcanic terrane onshore. The abundance of unaltered, extremely angular, and delicate-shaped glass shards and broken, unaltered mafic mineral euhedra in the sands offshore suggests a very recent pyroclastic origin and very little reworking or transport. They were apparently derived either from the erosion of very recent pyroclastic deposits or directly from explosive eruptions of the large Quaternary volcanoes. Probably both origins are represented by the sand layers. Sedimentation from a rapid depositional event is suggested for some of the layers by the presence of rip-up clasts, bioclastic debris (derived from the shelf), an abrupt base, and a poorly defined top.

\section{CONCLUSIONS}

There is a marked contrast in the composition of terrigenous sand between the southwestern Mexico and Guatemala portions of the Middle America Trench. Terrigenous sands offshore southwestern Mexico are rich in quartz, feldspar, and mafic minerals that closely reflect the schist and gneiss dominating the drainage basins onland. Terrigenous sands offshore Guatemala are dominated by pyroclastic debris that closely reflect the volcanic terrane onshore. In addition, the abundance of unaltered, extremely angular glass shards and pyroxene mineral euhedra suggests derivation from the prominent Quaternary andesitic volcanoes that parallel the coast.

An interpretation of provenance and depositional histories of ancient subduction complexes based on compositional studies of sands should take into account the possibility of significant changes in sand composition along the trend of a system, even though the nature of plate interactions remains constant over long distances.

\section{ACKNOWLEDGMENTS}

I am very grateful to J. Casey Moore of the University of California at Santa Cruz for our numerous discussions and his suggestions throughout the course of this research. His review of an early draft of this chapter was also very helpful. This study would not have been possible without the unhesitating cooperation of the scientists at the University of Texas Marine Science Institute, and I wish to extend special thanks to Ken McMillen for his continued interest in my research. Also very helpful at UTMSI were Trent Haines and Bill Behrens. 


\section{R. H. ENKEBOLL}

Core collection was supported by NSF Grant OCE-76-23300. Acknowledgment is also made to the Donors of the Petroleum Research Fund, administered by the American Chemical Society, for support of the laboratory portion of this research.

\section{REFERENCES}

Dickinson, W. R., 1970. Interpreting detrital modes of graywacke and arkose. J. Sediment. Petrol., 40:695-707.

Dickinson, W. R., and Suczek, C. A., 1979. Plate tectonics and sandstone compositions. Bull. Am. Assoc. Petrol. Geol., 63:2164-2182.

Karig, D. E., Cardwell, R. K., Moore, G. F., et al., 1978. Late Cenozoic subduction and continental margin truncation along the northern Middle America Trench. Geol. Soc. Am. Bull., 89: 265-276.

Ladd, J. W., Ibrahim, A. K., McMillen, K. J., et al., 1978. Tectonics of the Middle America Trench offshore Guatemala [paper presented at the International Symposium on the February 4, 1976, Guatemala earthquake and the reconstruction process, Agency for International Development, Guatemala City].

McMillen, K. J., Enkeboll, R. H., Moore, J. C., et al., 1980. Sedimentation and tectonics, Middle America Trench, southern Mex- ico and Guatemala [paper presented at the symposium, "Trench and Fore-arc Sedimentation and Tectonics in Modern and Ancient Subduction Zones," London].

Molnar, P., and Sykes, L., 1969. Tectonics of the Middle America regions from focal mechanisms and seismicity. Geol. Soc. Am. Bull., 80:1640-1694.

Moore, J. C., Watkins, J. S., Shipley, T. H., et al., 1979. Progressive accretion in the Middle America Trench, southern Mexico. Nature, 281:638-642.

Ross, D. A., 1971. Sediments of the northern Middle America Trench, Geol. Soc. Am. Bull., 82:303-322.

Salas, G., 1968. Carta Geologica de la Republica Mexicana, Comite de la Carta Geologica de Mexico.

Shipley, T. H., McMillen, K. J., Watkins, J. S., et al., 1980. Continental margin and lower slope structures of the Middle America Trench near Acapulco (Mexico). Mar. Geol., 35:65-82.

Spry, A., 1969. Metamorphic Textures: New York (Pergamon Press). Williams, H., 1960. Volcanic history of the Guatemala Highlands. University of California Publications in Geological Sciences, 38: 1-86. 